\title{
Editorial: Quality of life in cities
}

Derya Oktay BArch, MSc, PgDipUD, PhD

Professor of Architecture and Urban Design/Director of the Urban Research and Development Centre, Eastern Mediterranean University, North Cyprus/ Turkey

Over the past decades, quality of life (QOL) and more specifically, quality of urban life, has become a central issue for those who plan and study cities or places where people live in response to growing pressures on urban communities, concern about the impacts of urbanisation and the effects of this on the wellbeing of residents. Although QOL is an elusive concept, it can be accepted as the state of social wellbeing of an individual or group, either perceived or as identified by observable indicators (Pacione, 2005: p. 673). Considering the quality of life at the city scale, Mulligan et al. (2004) provide a more appropriate interpretation. They define QOL as the satisfaction that a person receives from surrounding human and physical conditions, conditions that are scaledependent and can affect the behaviour of individual people, groups such as households and economic units such as firms.

QOL has also been the subject of competitive evaluations through the classification of cities according to research results. Today, as the majority of the world's population resides in urban areas, the issue of QOL in cities needs to be explored more systematically through measuring and documenting the environment objectively and as it is experienced by residents. As highlighted by Marans and Stimson (2011: p. 2), investigating QOL in cities is important not only because it affects how people behave but also their life satisfaction and happiness. Additionally it has broader implications for research, urban policy, migration patterns, economic growth and environmental sustainability of communities and regions.

Planning, design and management of cities and neighbourhoods can play a vital role in enhancing QOL of urban residents although many other aspects of life (security, health, education, work, social ties, etc.) influence their wellbeing. The concept of QOL has also been linked to sustainable development such that unless we engage with more sustainable practices the quality of urban life will deteriorate.

With these aspects in mind, this issue of Urban Design and Planning focuses on the concept of QOL in cities and contributes to the debate on the concept of QOL as a key element of responsible urban design and planning.
The first paper focuses on the determination of the variables that affect liveability in cities. In particular, it deals with aspects of individual level happiness that are assumed to be one of the important predictors of QOL in a city. Goldberg et al. (2012), building upon recent research in five major cities, clarify how residents' perceptions of their cities as places to live and the quality of city services contribute to the happiness of urban residents.

The second contribution to this themed issue focuses on the adverse effects of conventional city form on public health. Toker and Minassians (2012), based on a comprehensive literature review, question the normative arguments for a good city and try to provide an operational definition of good city form which would accommodate a healthy community. In this context, the performance requirements for healthy communities are aligned with good city form components to emphasise the viability of city planning for sustainability. The paper also demonstrates the tangled components of city form with individuals' and communities' behaviour.

Understanding the extent of alternative urban planning and design techniques for inner and outer urban areas and housing environments in terms of enhancing overall QOL was another objective highlighted for discussion in this issue. The paper by Wynne (2012), in line with its sound objectives related to accessibility, people-friendliness, linkage and financial viability, provides practical lessons for QOL of the urban residents, building on the findings of his investigation on the successful transformation of Liverpool's city centre.

Urban life revolves around the places where people carry out their daily lives, and for most people, the residential environment is the central setting where this occurs. Creating a satisfactory housing environment is the most important social objective in urban development. In this vein, Rowland and Mitchell (2012) investigate the quality of environment and QOL aspects in the suburbs and question the relationship between the aspirations for QOL in the suburbs and the actuality on the ground. The paper, exploring the notions of power and empowerment, and control and individual action as 
essential dimensions of QOL, highlights the importance of integrating policies and processes to design issues when planning and developing suburbs.

In the fifth paper, Kirby and Glavac (2012) explore the highly popular assertion that extensive residential communities produced by corporate developers and marked by walls or gates are problematic and promote social fragmentation and alienation. By inserting the governance of residential space into the discussion of the relations between residential design and social outcomes the authors demonstrate the subjective evaluations of QOL offered by residents of low-density neighbourhoods in Arizona, where residential growth has mostly occurred in suburban settings. The findings of the quantitative study astoundingly point to a high level of personal satisfaction in the low-density neighbourhoods surveyed.

The final paper is concerned with quantity and quality of public open spaces, essential components of a good quality of urban life. Rofè et al. (2012), employing three different methods of evaluation (observation of activity, survey of residents' attitudes towards them and mapping feelings when walking through them), reveal that the problem with public open spaces in Israeli neighbourhoods is more a deficiency of quality, or of appropriate amenities for common use, rather than the quantity. The authors remind us that it is time to depart from the exclusive use of quantitative standards in assessing public urban space provision, and that quality and success must be measured by using diverse methods.

Taken together, the papers in this issue reveal the increasing attention on QOL in cities at various scales, and address a range of issues that should be of interest for academic researchers, policy makers, developers and citizens.

\section{REFERENCES}

Goldberg A, Leyden KM and Scotto TJ (2012) Untangling what makes cities liveable: happiness in five cities. Proceedings of the Institution of Civil Engineers - Urban Design and Planning 165(3): 127-136, http://dx.doi.org/10.1680/udap. 11.00031.

Kirby A and Glavac S (2012) Privatised development and the quality of urban life. Proceedings of the Institution of Civil Engineers - Urban Design and Planning 165(3): 167-175, http://dx.doi.org/10.1680/udap.11.00017.

Marans RW and Stimson R (eds) (2011) Investigating Quality of Urban Life: Theory, Methods, and Empirical Research. Springer, Dordecht, the Netherlands.

Mulligan G, Carruthers J and Cahill M (2004) Urban quality of life and public policy: A survey. In Advances in Urban Economics (R Capello and P Nijkamp (eds)). Elsevier Science, Amsterdam, the Netherlands, pp. 729-802.

Pacione M (2005) Urban Geography: a Global Perspective. Routledge, New York, USA.

Rofè Y, Feierstein G and Zarchin I (2012) Quantity and quality of public open spaces in Israel. Proceedings of the Institution of Civil Engineers - Urban Design and Planning 165(3): 177 187, http://dx.doi.org/10.1680/udap.11.00021.

Rowland J and Mitchell C (2012) The quality of life in cities: the twenty-first century suburb. Proceedings of the Institution of Civil Engineers - Urban Design and Planning 165(3): 157165, http://dx.doi.org/10.1680/udap.11.00015.

Toker Z and Minassians H (2012) Good cities and healthy communities in the USA. Proceedings of the Institution of Civil Engineers - Urban Design and Planning 165(3): 137145, http://dx.doi.org/10.1680/udap.11.00016.

Wynne B (2012) Liverpool's appetite for change. Proceedings of the Institution of Civil Engineers - Urban Design and Planning 165(3): 147-155, http://dx.doi.org/10.1680/udap. 11.00022 